\title{
INTERRELIGIOUS ORIENTATIONS AMONG SOUTH AFRICAN YOUTH
}

\author{
Jaco S Dreyer, Hendrik J C Pieterse \& \\ Johannes A van der Ven
}

\begin{abstract}
In this article we investigate the interreligious orientations of a sample of 538 students from Standard 9 (Grade 11) who attended Anglican and Catholic schools in the Johannesburg/Pretoria region during 1995. In the first part of the article we describe the religious diversity of South Africa. This religious diversity was neglected in the past, but due to the establishment of the first democratically elected parliament and the adoption of a new constitution, we have entered a new situation in South Africa. Despite these changes, we still face the challenge to realise the democratic vision. Against this background, we direct our attention to two questions: What are the interreligious orientations of the South African youth, and how do they evaluate these interreligious orientations? Based on theological models of the meeting between religions we conceptualised four interreligious orientations: exclusivistic, inclusivistic, relativistic and dialogic. The relativistic orientation receives empirical support, but these students do not distinguish between exclusivistic and inclusivistic interreligious orientations. An unexpected finding is the distinction between subjective and objective dialogic orientations. These students are negative towards an absolutistic (exclusivistic and inclusivistic) orientation, and favour a relativistic interreligious orientation.
\end{abstract}

\section{Introduction}

We live in a postmodern age characterised by pluralism and diversity. The mass media constantly remind us of the social, cultural and political diversity of our 'global village'. This reality of pluralism and diversity, however, is not something that we can experience from a detached, observer perspective. Our daily experiences confirm that we South Africans live in a multicultural and pluralistic society. To use Archbishop Desmond Tutu's well-known image, we are indeed a 'rainbow nation'. 
Despite the richness, challenges and growth potential that this diversity brings, we are also painfully aware of the problems and tensions that often arise from this diversity. Social, economic, cultural and political diversities often seem to be catalysts for wars, conflict and all sorts of violence. One of the main challenges of our time is dealing constructively with this pluralism and multiculturalism (cf Gutman 1994).

Religious diversity is an important part of the pluralism and diversity of our times. The days are gone that the world religions could be related to specific geographical areas on our planet. The massive migrations of people in this century as well as the communication explosion have led to multifaith societies in many parts of the world. There are no longer oceans separating Christians from adherents of other faiths, and Christians, Muslims, Hindus, Sikhs and Buddhists rub shoulders on every street in Western countries, writes Bosch (1991:475). Despite processes of modernisation and rationalisation, religion and religious issues still seem to be part of the fabric of modern societies. It is common knowledge that religious conflicts are often in some way intertwined with many of the conflicts all over the world, for example in Northern Ireland and the Middle East. These conflicts are not only between the world religions,' but also within religions (such as the CatholicProtestant antagonism in Northern Ireland). This leads to the view that world peace depends among other things on peace among the various religions (cf Küng in Küng et al 1993:441). ${ }^{2}$ Even in less extreme cases religious diversity has some conflict potential and is often experienced as a problem. There seems to be a renewal of the traditional bond between religion and nationalism in certain societies and an increase in the kind of religious expression associated with fundamentalist and national religious expansion through religious communities catering for racial, ethnic and social identities (To \& Tulasiewicz 1993:178; cf Bosch 1991:476). Even established democracies seem to struggle with this religious plurality as part of multicultural societies, ${ }^{3}$ as multiculturalism and religious diversity often go hand in hand. There seems to be a conflict between 'collective identities', including collective. religious identities, and individual identities. With religion, the conflict potential of collective religious identities is enhanced because of the truth claims that are inseparably part of these identities. The exclusiveness of religious claims thus has the potential to increase intolerance.

Religious diversity and the problems it creates cannot be ignored today in most parts of the world. Against the background of religious 
diversity and the problems it poses, the following questions are of more than academic significance at the dawn of the third millennium: How can people of different faiths and with different religious identities live justly and harmoniously together in a multireligious, democratic society which is increasingly growing into a 'global village'? (cf Ziebertz 1993:89). What kind of interaction between the world religions do we need? (Van der Ven 1994:246). These important questions form the background to this article. In the first part of the article we explore the problem of religious diversity in the South African context with its changing political situation. In the second part we explicate the theoretical framework for our empirical research on interreligious orientations. In the third part we discuss the results of empirical research on the interreligious orientations of a section of today's South African youth. In the concluding part we reflect briefly on the research results in the light of the religious diversity in South Africa.

\section{Religious Diversity in South Africa}

Since the establishment of the first democratically elected Parliament in 1994 South Africa has had a new political structure. Although South Africa is legally and politically a democracy, we are now faced with the major challenge of building up new economic, social and cultural structures in this multicultural land. But South Africa does not only need the strengthening of the democratic system - more than this, we are faced with the task of realising the democratic vision (cf De Gruchy 1995:7). ${ }^{4}$ In De Gruchy's (1995:7) words, a democratic vision refers among other things 'to that hope for a society in which all people are truly equal and yet where difference is respected'. The challenge of realising this vision was echoed by the Cape Town Conference of the South African member churches of the World Council of Churches in 1992, which called for the creation of an ethos of multicultural respect and tolerance in our divided country (cf De Gruchy 1994:18-19).

The realisation of this democratic vision seems to be particularly difficult in South Africa because apartheid led to the annihilation of the fundamental human values that are important preconditions to democratic order. In De Gruchy's (1994:19; De Gruchy 1995:218) words: 'A respect for free speech as well as tolerance for the views of others have been casualties of the struggle against apartheid ...' It is against this background that the problem of religious diversity gains 
prominence, because the intolerance of the beliefs and opinions of others is one of the most serious dangers facing South Africa (De Gruchy 1994:21). De Gruchy therefore pleads for interfaith tolerance and cooperation.

Is this call for interfaith tolerance necessary in such a 'Christian country' as South Africa? ${ }^{55}$ We believe it is, given the religious plurality of this country. This diversity was often neglected in favour of Christianity. ${ }^{6}$ According to Prozesky (1995:1) the history of South Africa shows that there was no equality of faiths. One of the ways in which the religious diversity was obscured was precisely by creating an image of South Africa as a 'Christian country'. The claim that South Africa is a Christian country is usually based on statistics from government censuses. According to the 1991 census $^{7}$ about $95 \%$ of those who answered the question regarding the religious group they belonged to indicated that they were affiliated with a Christian community (J J Kritzinger 1993:2; Population Census 1991). Of these Christians, about $40 \%$ are committed to mainline Protestant churches (Dutch Reformed Churches 18\%, Methodist Churches 9\%, Anglican Churches 6\%, Lutheran Churches 4\%, Presbyterian Churches 2\%), 34\% to African Independent Churches, to which an estimated 4000 different churches belong, $11 \%$ to the Catholic Church, $7 \%$ to the Zion Christian Churches, and the rest to other Christian churches.

The statistics that are often used to indicate that South Africa is 'overwhelmingly Christian's tend to underplay the fact that a vast section of the total population, $30 \%$ in the 1991 census, did not answer the question about their religions or objected to it." It is probably more accurate to say that roughly two thirds of the population indicated that they belong to a Christian community. ${ }^{10}$ Even this figure obscures the religious diversity (cf Krüger 1994; Chidester 1992; Chidester et al 1994:16 - 17). First, Christianity is not a homogeneous, single tradition in South Africa, but 'a diverse category, encompassing many different Christian affiliations, with varying doctrines, practices, and forms of organization' (Chidester et al 1994:16). ${ }^{11}$ The designations 'Christian' and 'Christianity' thus obscure the religious plurality within Christianity. Roughly a third of the total number of Christians belong to the socalled African Initiated Churches. Then follow the Reformed family (18\%), Catholics (11\%), the Methodists (9\%), Anglicans (6\%) and Lutherans (4\%) (Krüger 1994:4 with reference to the 1991 census). Nor is this intrinsic pluralism, as Omar (1991:50) calls it, peculiar to Christianity; it is characteristic of all the major religious traditions in 
our country (Omar 1991:49-50)..$^{12}$

Second, nearly all the'world religions' are represented in South Africa (cf Chidester 1992:148). ${ }^{13}$ Chidester (1992:148) mentions that Muslims, Hindus and Jews, along with other religious traditions such as Buddhists, Confucians and Parsees, made up roughly 5\% of the South African population by 1980 . According to the 1991 census $1,3 \%$ of the population claimed to be Hindus (about 477000 ), 1,1\% Muslims $(412000)$ and $0,2 \%$ Jews $(81000)$. Despite the relatively small number of adherents to other 'world religions',"1 it can be claimed that South Africa has an exceptionally rich diversity of religions (Prozesky 1995:1). ${ }^{15}$

This religious diversity was obscured in the past because of the powerful position of Christianity throughout the history of South Africa. Although the Republic of South Africa Constitution Act 110 of 1983 (like the constitutions of 1910 and 1961) contained a constitutional confession of faith, "'i it did not constitute a rule of law, and South Africa was not a Christian state with an official state religion, nor was the South African legal system a religious system (Van der Westhuizen \& Heyns 1993:99). In theory, therefore, religious freedom existed in South Africa under the apartheid regime (cf Van der Westhuizen \& Heyns 1993:99).

In practice, however, things were quite different. According to Prozesky (1995:1) the history of South Africa shows that there was no equality of faiths. The religious situation thus resembles the inequalities and injustices of the sociopolitical and other spheres of our society (Prozesky 1995:1-2). ${ }^{17}$ In apartheid South Africa the Christian religion was privileged above all the other religions. ${ }^{18}$ Van der Westhuizen and Heyns (1993:99-100) mention that the South African law shows a strong preference for Christianity. Examples of this bias can be found in the Preamble to the 1983 Constitution that explicitly lists the upholding of' 'Christian values', the idea of 'Christian national education' '19, censorship laws that referred to the upholding of a Christian view of life ${ }^{21}$ and Sunday observance laws and Christian religious public holidays. This privileging of Christianity was also evident in other ways. Public religious broadcasts, especially on television, and state subsidies for theological training (especially Dutch Reformed theological training) greatly favoured Christianity (cf Saayman 1993:42; Van der Westhuizen \& Heyns 1993:100). ${ }^{21}$ Saayman (1993:42) also argues that the religious status of Muslims and Hindus in the apartheid context with its 'racist institutionalisation of all aspects 
of life' was inferior because these religions are almost exclusively 'black' religions. ${ }^{22}$ Thus one can conclude that although other religions were mostly tolerated, religious freedom did not really exist as public life operated on the assumption that Christianity is superior to other religions, and Christian political power ${ }^{23}$ ensured that this dominance was maintained in all spheres of public life (cf Saayman 1993:41-42).

However, it is important to point out that this lack of religious freedom did not emerge only for religions other that Christianity. Even the religious freedom of Christian churches was compromised by state intervention in religious affairs. According to Van der Westhuizen and Heyns (1993:100) the South African government has often interfered with the work of churches, especially when these were perceived to oppose the state's apartheid and security policies. Examples of state intervention are the deportation of missionaries, breaking up of services and processions, and the banning of the Christian Institute of South Africa. Villa-Vicencio (1992:263-264) mentions several examples of state intervention in religious freedom. According to him, one of the best illustrations was the introduction of what became known as the 'church clause' by the then Minister of Native Affairs and one of the main architects of apartheid, Hendrik Verwoerd. This 'church clause' was introduced to impose racial segregation in the worship services of the non-racial churches, and after protest from these churches was modified to allow the state to prevent black Christians from worshipping with white Christians if anyone should complain that they were a 'nuisance' or were worshipping in 'excessive numbers'. In 1983 the Eloff Commission condemned all forms of political theology and as late as 1987 the Commissioner of Police made it illegal for churches to call for the release of political detainees. Although some of the mainline Christian churches were discriminated against under apartheid, it should be added that the African Initiated Churches (AICs) were particularly hard hit. They were often seen as 'hotbeds of African nationalism', and therefore not treated as 'recognised' churches who could own property or qualify for church stands (cf Claasen 1995).

This situation changed dramatically after the establishment of the first democratically elected Parliament in 1994. The new government. embarked on the process of constitution making through its Constitutional Assembly and wide consultation. On 10 December 1996 President Nelson Mandela signed the final Constitution into law and on 3 February 1997 South Africa's new Constitution came into effect after months of consultation and negotiation between the major political 
parties. ${ }^{24}$ This marks the end of a long process in which South Africa moved to a democracy in which the Constitution is sovereign (Report on Christianity, the secular state and constitutionalism 1996:80). With this new Constitution South Africa finally became a fledgling member of the democratic family on our planet.

The new Constitution has important implications for the relation between state and religion. Whereas the 1983 Constitution (like its predecessors in the 1910 and 1961 constitutions) started with a constitutional confession of faith (cf Du Plessis 1996:60—61), this is not so with the new Constitution. ${ }^{25}$ South Africa has become a constitutional secular state ${ }^{2 / i}$ in which religious freedom and the protection of religious rights are guaranteed through its Bill of Rights. Thus Section 15(1) of the Constitution reads as follows: 'Everyone has the right to freedom of conscience, religion, thought, belief and opinion.' According to Du Plessis (1996:66) this clause protects more than freedom of religion in the strict sense of the words, and includes the right not to observe any religion and the right not to believe. This right is also supported by other rights such as the right to equal protection and benefit of the law that prohibits discrimination on the grounds of (among others) religion, conscience or belief, ${ }^{27}$ and the freedom of expression, assembly and petition. ${ }^{2 x}$ The final Bill of Rights also recognises (but does not guarantee) the right of people who belong to a cultural, religious or linguistic community to enjoy their culture, practise their religion, use their language, and form, join and maintain cultural, religious and linguistic associations and other organs of civil society.?

This loss of Christian political power ${ }^{311}$ and the change to a truly secular state with a new Constitution and a Bill of Rights led to a growing awareness of the problem of religious diversity in this country, especially among those Christian communities that benefited from the political power of apartheid South Africa. ${ }^{31}$ Although the majority of the people of our country claim to be 'Christians' in some way or another, there is now greater awareness of religious diversity through the mass media (specifically religious programmes on $\mathrm{SABC}$ television), the religious observances at state functions (such as the inauguration of President Mandela) which reflect the religious diversity of our country, and the increasing interaction between people from different cultural backgrounds, and in schools too. There is also growing awareness that our actions must be consistent with the new Constitution, which guarantees freedom of religion and prohibits any discrimination on religious grounds. ${ }^{32}$ 
The interests of Christian communities are no longer 'protected' by the state or public policy-making. Christian communities have to accept the challenge that faces all religious communities, namely how to deal with the religious diversity in a truly democratic spirit. This means, in the words of Lubbe (1995:33), accepting people of other faiths 'as colleagues, neighbours, friends and fellow citizens'.

Against this background of discrimination against people of other faiths, and the need to build a truly democratic ethos, it is important to establish the attitudes or orientations of citizens of South Africa towards other religions. Even more important, we would like to know the interreligious orientations of the youth, those youngsters who will be tomorrow's leaders and who will have to work toward realising the democratic vision in our country. Do they exhibit interreligious orientations that could contribute to equality, tolerance, justice, peace and respect and the realisation of a democratic vision? Or do they hold interreligious orientations that could possibly contribute to tension, intolerance, religious apartheid, injustice, disrespect, religious fanaticism and religious authoritarianism in a divided South African society?

Two questions direct our attention. What are the interreligious orientations of South African youth? How do they evaluate these interreligious orientations?

Before we try to answer these questions from a survey conducted in 1995 we explain the theoretical framework for our empirical research.

\section{Interreligious Orientations}

Growing awareness of the religious diversity of our 'global village' not only poses problems on a sociopolitical level, it is also one of the main problems of theology today (cf Race 1983:ix-xi; Waldenfels 1990:67). 'To say that we live in a religiously plural world is not new. What is new, however, is the increasing awareness that this brings with it serious theological issues for the Christian church' (Race 1983:1). This awareness has brought many disconcerting questions in its wake and poses a serious challenge to the traditional self-understanding of Christians (cf Netland 1986:20). Why are there so many different religions? How should we, as Christians, approach the meeting between the world religions? How should we see the relationship between Christianity and the other world religions? How should we see the New Testament's 
claim of the uniqueness and absoluteness of Christ? (cf Ziebertz 1992:86). How should we respond to the diversity of humankind's religious life? (cf Race 1983:ix). These are all important questions, because the answers are vital to the establishment of our religious identities in a religiously plural world. These questions have received much attention in the last decade or so in a new specialism of the Christian theological enterprise (Race 1983:xi), the 'theology of religions'. This branch of theology endeavours to deal in a theologically responsible way with the serious theological challenges of religious plurality. Ziebertz (1992:85) even says that it 'seems as if an epoch in theology is coming to an end, which has concentrated on doing theology within the limits of Christian revelation and negating all other religions that ultimate validity, which it claims for its own conviction'.

At the heart of the traditional approach to 'theology of religions' is the issue of the relationship of Christianity to the other world religions. This is not, of course, a new issue. The history of the problem of Christian attitudes to adherents of other faiths is ancient, with roots in the Old Testament (Bosch 1991:474). It is only in recent times, however, that the issue has become prominent again. ${ }^{33}$ Knitter (1985:18) says that the main stumbling-block for Christian theology in the face of religious pluralism is the traditional self-understanding of Christianity as unique, exclusive, superior, definitive, normative, and absolute. Is this Christian self-understanding mistaken? Is Christianity indeed essentially different and something special? (cf Bosch 1991:477).

The urgency to respond theologically to this question has led to a vast number of publications and theological positions. Bosch (1991:478), for example, refers to the work of Klaus Nürnberger, who as early as 1970 identified 27 types of response. Knitter (1985) also refers to the difficulty of classifying the variety of attitudes towards other religions. In his overview of current models of Christian understanding of other religions, Knitter (1995:25) says that terms are either too ambiguous or too strictly defined, that models blur differences or simplify complexities, and that different starting-points or criteria lead to different models. As an example he refers to his own classification (1995) that takes a confessional perspective as the point of departure: the conservative evangelical approach ('Christianity is the one true religion'), the mainline Protestant approach ('other religions contain revelation but no salvation'), the Roman Catholic approach ('other religions may be true and good but need fulfilment in Christ'), and the theocentric approach ('there are many ways to the 
one Divine Centre'). However, by taking a christological perspective as a basis for classification, the following categories might be distinguished: Christ against the religions (a negation of the value of other religions); Christ within the religions (Christ as a universal saving presence); Christ above religions (Christ not as the cause of salvation, but as the fullest embodiment of salvation); and Christ together with the religions (Christ as one of many possible saving figures and manifestations of truth) (Knitter 1995:25).

Many other 'classifications' or 'typologies' of the relation between Christianity and other religions can be found in the theology of religions with no apparent or emerging consensus (cf Bosch 1991:478) ${ }^{31}$ One of the most 'popular' typologies, however, is proposed by Race (1983), exclusivism, inclusivism and pluralism. ${ }^{35}$ According to Race (1983:7) these models give a broad typological framework within which most current Christian theologies of religions can be placed. 'The essence of exclusivism is that salvation is only possible through Jesus Christ (cf Acts 4:12; John 14:6), and revelation in Christ is the sole criterion by which the relationship between Christianity and other faiths can be understood and evaluated (cf Race 1983:10-11). ${ }^{36}$ Race (1983:24) says that this model is the most clear-cut, because it involves no complicated theory of religious experience; it appeals to 'what for many is a self-evident biblical witness', it is logical and it corresponds most closely to the orthodox Christian view through the centuries. ${ }^{37}$ The model of inclusivism, with its roots in the early Christian tradition, implies both an acceptance and a rejection of other faiths, a dialectical 'yes' and 'no' (Race 1983:38). Although this approach accepts that the grace of God is also at work in the other religions, it maintains the uniqueness of Christ and the superiority of Christianity. Within this view, the Christian religion is regarded as 'the seed' for other religions. Two equally binding convictions have to be kept in balance, the universal will of God to save, and the uniqueness of the revelation in Christ (Race 1983:54). Although different strands of the inclusivistic approach can be distinguished (cf Race 1983:68-69), it is usually associated with the Roman Catholic Karl Rahner's theory of 'anonymous Christianity' (cf Race 1983:43-50; Hick 1985:33-34). ${ }^{38}$ In comparison with the models of exclusivism and inclusivism which can both claim 'ample pedigree in the Christian tradition' (Race 1983:70), the model of pluralism belongs to the modern period. ${ }^{3 !}$ This model stresses that the knowledge of God is partial in all faiths, including Christianity, and that religious truth cannot escape cultural relatedness (cf Race 
1983:72; 76; Netland 1986:22). ${ }^{\text {t1 }}$ According to Race (1983:77) the pluralist position seems to give the simplest solution to the problem of religious diversity.

Although there seems to be much consensus regarding the models of exclusivism and inclusivism, the third model in Race's typology, pluralism, is problematic. Knitter (1995:23) laments the often stereotyped image of the pluralist model and stresses that a 'plurality of pluralists' exists. ${ }^{41}$ It is thus better to speak of different versions of a pluralistic theology of religions. We distinguish here only the relativistic and dialogic versions of pluralism.

The core idea of relativistic pluralism ${ }^{42}$ is that the various religions are in principle equal. All religions are merely branches of the same tree. From a phenomenological perspective this implies that God's salvific work takes different forms in different cultures and historical periods. These cultural differences, however, are not substantial and of little importance because behind them is the one God (Ziebertz 1993:90; 1994:153,157). From a psychological perspective the equality of religions is linked to the common divine soul present in the "collective subconscious' (in Jung's terms) of humankind. Although myths and symbols differ according to culture, the core of this archetype remains identical (Ziebertz 1993:90-91; 1994:153-154,157). All religions give expression to the human being's emotional search for happiness and joy (Van der Ven 1994:250). One of the weaknesses of this model is that it runs the risk of reductionism in which the religious dimension is reduced to the philosophical (phenomenological) or psychological equality referred to above. In this way the intrinsic value of religion, namely as human engagement with transcendence, is lost. Another potential problem of religious relativism ${ }^{43}$ is that it can end in religious indifferentism (Van der Ven 1994:250).

The relativistic version of pluralism has led authors such as Knitter (1995; 1996), Küng (Küng et al 1993), ${ }^{11}$ and Tracy (1990) each in his own way to stress the importance of interreligious dialogue within a pluralistic approach which takes otherness and difference between religions seriously. Instead of accepting a pluralistic theology of religions in which the 'the real diversity among religions becomes submerged in a placid sea of sameness' (Knitter 1995:31), this 'dialogic approach' opts for a critical correlational dialogue in which all sides are able to hear and at the same time to speak to and challenge in return (Knitter 1995:24; cf Küng et al 1993:xix; Tracy 1990). An important element of this approach is that there should be dialogue or communication 
between one's own and other religions. This dialogue, however, should not be conducted from an 'I' perspective only, in which one's own religion is taken as the most valuable way to salvation or religious truth such as the exclusivistic and inclusivistic models imply. Nor should this dialogue be conducted only from a neutral 'it' perspective, in which personal involvement with religious matters is avoided, such as in the relativistic model. The core of this model is that the dialogue between religions should be characterised by a perspective exchange. This presupposes not only an established religious identity and personal engagement with religious matters in a specific religious tradition, ${ }^{45}$ but also the ability and the willingness to interpret other religions from their own perspectives. Such a perspective exchange thus implies a double, reciprocal auto- and allo-interpretation of one's own and the other religion (cf Waldenfels 1990:18-21). This model, which is based on the principle of dialogue, reflects a relational notion of the truth and can be regarded as a modern theological orientation to the problem of religious diversity (cf Ziebertz 1993:91 — 92). It also implies a striving for mutual understanding, tolerance and respect as well as self-reflexivity and self-criticism. Van der Ven (1994:253) states that this model is based on humanistic values such as the right to conscience, the right of religious freedom (between and within religions), and the intrinsic worth of the individual human being.

We are dealing with interreligious orientations among South African youth. We distinguished four interreligious orientations (exclusivistic, inclusivistic, relativistic and dialogic) based on these theological models on the meeting between religions in order to try to answer the question regarding their interreligious orientations. The four orientations were operationalised by four items each, which resulted in a set of 16 questions. ${ }^{4 i}$ We operationalised the exclusivistic orientation in our research with items such as 'Only in my religion can people receive true salvation' and 'My religion contains the one, true light of redemption'. The inclusivistic orientation was operationalised in items such as 'Compared with my religion, the other religions contain only part of the truth' and 'Compared to the other religions, my religion contains the supreme salvation'. Examples of our conceptualisation of the relativistic orientation are items such as 'All religions are equally valuable, they form different ways to the same salvation' (the phenomenological perspective) and 'There is no difference between religions; they all stem from a longing for God' (the psychological perspective). Lastly, the dialogic orientation was operationalised in items such as 'The way 
to real salvation is only to be found in dialogue between the religions' and 'Before finding authentic (real) redemption religions must enter into dialogue with each other'.

\section{Interreligious Orientations of a Sample of South African Youth}

We have referred above to the importance of empirical research in order to try to establish the attitudes of the peoples of this country, especially the youth, towards adherents of other faiths. To investigate these attitudes we included the questions on 'interreligious orientations' in a survey we conducted in 1995 among a specific section of South African youth. This sample approaches the empirical universum of Standard 9 students in both church-affiliated schools in the Johannesburg/Pretoria region. ${ }^{47}$

Now we are able to try to answer the question we asked at the end of the first part of the article: What are the interreligious orientations of South African youth? This question can be formulated in a more specific way. Do the orientations of South African youth reveal the same structure as the conceptual structure (see figure 1) suggests? In other words, are their orientations towards other religions divided into exclusivistic, inclusivistic, relativistic and dialogic orientations?

Figure 1: Interreligious Orientations

Interreligious orientations

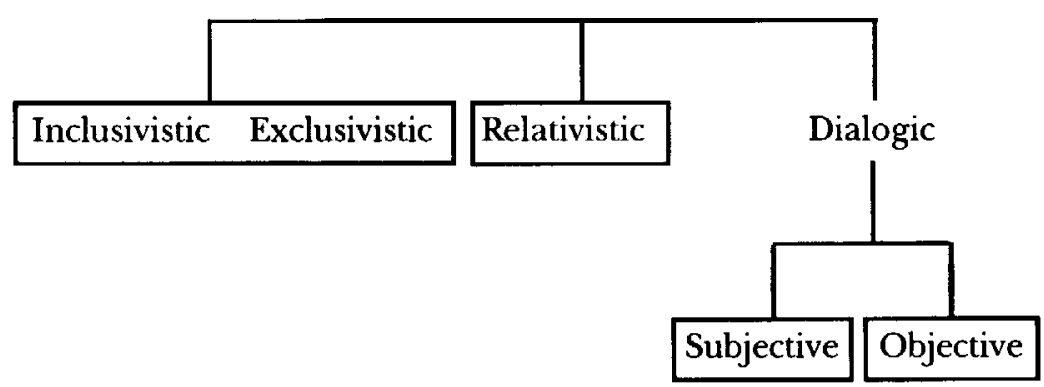


To answer this question we conducted an overall factor analysis on the answers given by these Standard 9 (Grade 11) students. For statistical reasons, two items had to be eliminated..$^{18}$ Four factors were extracted from the students' responses to the remaining items. As figure 1 shows, only the relativistic orientation receives empirical support. ${ }^{49}$ The distinction between exclusivistic and inclusivistic orientations, however, does not seem to apply in the empirical domain. These respondents do not distinguish between exclusivistic and inclusivistic orientations. Empirically, these variants are not distinct but form one factor. ${ }^{50}$ Underlying both the exclusivistic and inclusivistic orientations is the absolutistic claim that my religion is the only true religion (cf Sterkens, Hermans \& Van der Ven 1997:11). ${ }^{51}$ We therefore labelled this factor the absolutistic orientation.

Contrary to our expectations, we found that the dialogic orientation does not form one factor, but two. This indicates that two empirically distinct dimensions regarding the dialogic orientation as we conceptualised it can be distinguished. A possible reason for this result is that the respondents were inconsistent in their answers and the reliability of the responses has to be questioned. This is unlikely, because of the apparent consistency in the response patterns on the other concepts. A second possibility is that no clear position regarding dialogue with the other faiths has yet crystallised in the minds of these students, and their responses to these closely related items therefore show some inconsistency or ambivalence. The question then arises whether this does not also apply to the other models that we have distinguished. Why will their ideas towards dialogue with other religions be less crystallised than towards the other models that we have distinguished? A third possibility, and the one that we find most likely, is that the operationalisation of the dialogic orientation is not unidimensional, that is that some other dimension is present in the items which we overlooked.52 On close inspection of the two factors it became clear that two underlying dimensions are indeed present in our operationalisation of the dialogic orientation. The first refers to dialogue from a personal, subjective perspective, while the second factor seems to stress dialogue from a more objective and impersonal perspective. Although the respondents are most probably not aware of the theologies of salvation and differences in 'salvation language', the different words used in the items of the two factors, respectively salvation and redemption, strengthen the above interpretation of a distinction between subjective and objective dialogic orientations. According to Rahner 
and Vorgrimler (1983:458) the term salvation 'does not primarily signify an "objective" achievement ... but rather a "subjective", existential healing and fulfilment of life'. It is not only salvation in a general objective sense that is at stake in the interreligious dialogue, but my salvation..$^{53}$ In contrast, the term redemption ${ }^{54}$ in the Christian sense refers to an 'objective' event. ${ }^{55}$ The subjective-objective distinction also makes sense regarding the wording of the other two items, ${ }^{56}$ namely 'God' and 'real truth' as the object of the dialogue between the religions. The aim of the interreligious dialogue can be seen as the search for real truth, which has the connotations of objectivity, universality and impersonality, in contrast to the search for God which refers to a much more personal and subjective event.

Table 1: Factor correlation matrix of interreligious orientations

\begin{tabular}{|c|c|c|c|c|}
\hline & Absolutistic & $\begin{array}{l}\text { Dialogic } \\
\text { (subjective) }\end{array}$ & $\begin{array}{l}\text { Dialogic } \\
\text { (objective) }\end{array}$ & Relativistic \\
\hline Absolutistic & 1.00 & & & \\
\hline $\begin{array}{l}\text { Dialogic } \\
\text { (subjective) }\end{array}$ & -.04 & 1.00 & & \\
\hline $\begin{array}{l}\text { Dialogic } \\
\text { (objective) }\end{array}$ & -.04 & .45 & 1.00 & \\
\hline Relativistic & -.65 & .33 & .30 & 1.00 \\
\hline
\end{tabular}

How do these factors relate to each other? As one can expect, there is a negative correlation between the absolutistic and relativistic interreligious orientations (table 1). These orientations seem to be each other's opposites. This is confirmed by the strong, negative correlation ( $r$-.65) between the two factors, which means that the higher these respondents value a absolutistic orientation, the lower they will value a relativistic orientation, and the other way round. ${ }^{57}$ The relatively strong positive correlation $(\mathrm{r} .45)$ between the subjective and objective dialogic orientations is also no surprise (see above). It is interesting to note that the relativistic orientation has a moderate, positive correlation with both the subjective ( $r .33)$ and the objective ( $r .30)$ dialogic orientation. This can be interpreted against the background of the debate on the theology of religions (see above) on the different 'versions' of pluralism. Although the relativistic and the two dialogic orientations are 
empirically distinct, they all give expression to a pluralistic interreligious orientation.

The question now arises whether differences exist in the valuations of these interreligious orientations. In other words, is there a specific interreligious orientation that these youngsters value more highly than the other? In table 2 we see the average scores on the different interreligious orientations. ${ }^{58}$

Table 2: Valuation of the interreligious orientations

\begin{tabular}{|lc|}
\hline & Average \\
Absolutistic orientation & 2.5 \\
Subjective dialogic orientation & 2.7 \\
Objective dialogic orientation & 3.3 \\
Relativistic orientation & 3.8 \\
\hline
\end{tabular}

The respondents in our population are clearly negative about an absolutistic orientation. ${ }^{59}$ This orientation, which claims uniqueness and/or superiority for one's own religion in the meeting between religions, received the lowest average score from our respondents. As a group they reject such an orientation to other religions. Regarding the two dialogic orientations that we have distinguished above, they clearly favour an objective dialogic orientation. This means that they prefer dialogue between religions to be conducted from an objective, distant perspective rather than from a subjective and personal faith perspective.

The highest average score (3.8) is obtained for the relativistic orientation. ${ }^{6 / 1}$ As a group these students are positive towards such an orientation in the meeting between different faiths, that is, they favour an orientation which regards all faiths as equal, which values the common core of all religions more than the cultural particulars of the different religions, and which relativises the special truth of a specific religion (cf Ziebertz 1993:93,96). The answer to the above question is that these students clearly favour the relativistic as opposed to the other three orientations.

Why do they favour a relativistic orientation? We suggest three possibilities. First, it may be a youth phenomenon. Ziebertz (1993:97), with reference to Nipkow's work (cf Nipkow 1994:224), maintains that a relativistic attitude regarding the multitude of religions is widely popular among students. ${ }^{\text {il }}$ Second, this result may be expected, given 
recent sociopolitical changes in South Africa, with the concomitant establishment of a secular state, the stress on religious freedom, tolerance and a democratic ethos from political and religious leaders, and the call to transcend cultural and other differences with slogans such as 'One country, one nation' and 'We are one'. Third, this finding also makes sense if one considers the 'democratic ethos' of the schools that our respondents attend. Although these schools are private church schools, they are not exclusively for people from these denominations. ${ }^{62}$ Furthermore, not only students who identify with a Christian church or denomination attend these schools, but also students who prefer other, non-Christian religions or no religion at all. ${ }^{63}$ These schools have a history of actively striving for tolerance and respect for cultural and religious differences, and were racially integrated even in the heydays of apartheid. ${ }^{\text {i1 }}$

\section{Conclusion}

We referred above to a very important question, namely how people of different faiths and different religions can live justly and harmoniously together in a multireligious, democratic society. What can we deduce from our research among a sample of the youth of South Africa regarding this important question? What do we learn from the orientations of the youth of South Africa towards religious diversity? Against the background of apartheid, the discrimination against faiths and the general lack of a democratic ethos and vision (De Gruchy 1995) the research results are indeed encouraging. ${ }^{65}$ The students who took part in our research are clearly negative about an absolutistic interreligious orientation, with its implied attitude that I am right and everyone else is wrong (cf Cooling 1994:36), and positive towards a relativistic interreligious orientation, with its implied religious tolerance and respect for others. ${ }^{\text {ifi }}$

Although we view these results in a positive light, we have to point out that the relations between orientations and actions are not simple and linear. ${ }^{67}$ We cannot take for granted that a relativistic orientation will lead to inter-faith tolerance. On the other hand, we also cannot assume that a person with an absolutistic orientation will necessarily act intolerantly towards people of other faiths. We have to keep in mind that the relationships between cognitive, affective and behavioural components are much more complex than was once assumed (cf Van 
der Ven 1993:136 - 137). Acconding to Van der Ven (1993:137) behaviour seems to be determined by factors other than mere cognitions and affects, such as intentions, action priorities, and the contextuality of time and place. Attitudes and orientations therefore cannot be used as predictors of the behaviours that would logically correspond to them (Van der Ven 1993:137). Netland (1986:24) illustrates this point with regard to interreligious orientations and actions when he says that the widely accepted equation of exclusivism with intolerance is misleading:

'To be sure, history provides ample evidence that exclusivists of all faiths have acted in intolerant and barbarous ways to adherents of other faiths. But there is no necessary connection between holding a given group's religious beliefs to be false and the radical mistreatment of members of that group. Surely one can consider the beliefs of another to be false and yet treat that individual with dignity and respect.'

Although we can conclude that there is no one-to-one relation between interreligious orientations and specific actions in the interfaith praxis, we have to stress that this does not imply that there is no relationship at all (cf J N J Kritzinger 1997). The question remains, however, how these youngsters will act towards adherents of other faiths in concrete, and often conflicting, situations. Based on our research, we can at least say that there are positive signs on the road to the realisation of our democratic vision.

Department of Practical Theology University of South Africa

P O Box 392, Pretoria, 0003

JACO S DRFYER

Republic of South Africa

E-mail: dreyejs@alpha.unisa.ac.za pietehjc@alpha.unisa.ac.za j.vdven@theo.kun.nl

I Küng (Küng et al 1993:442) mentions the Vietnam War (antagonism between Buddhist monks and the Catholic regime), the conflict between India and Pakistan because of the 'irreconcilable hostility' between Hindus and Muslims, the war between Iran and Iraq, and the Middle Eastern conflict where Muslims, Jews and Christians confront each other. He also remarks that the "most fanatical, the cruelest political struggles are those that have been colored, inspired, and legitimized by religion'. 
2See Waldenfels (1990:352-359) for a less optimistic view of the role of religions regarding world peace.

${ }^{3}$ Sanneh (1993:184-229) refers to the striving for religious territoriality as one of the challenges posed by religious groups that have entered the West since the 1960s. According to him, this striving for religious territoriality in Western societies that have more or less become accustomed to the separation of Church and State, ie non-territoriality, poses a severe threat to religious minorities in multifaith societies and puts Christians generally in a defensive position.

4 '...adoption of the democratic system is not the realization of the vision' (De Gruchy 1995:223).

"South Africa is often popularly described as 'a Christian country' (cf Van der Westhuizen \& Heyns 1993:99). Incidents like the recent bombing of a mosque in Rustenburg, apparently by right-wing extremists whose demands include the release of 'boere freedom fighters', a self-governing territory, unconditional amnesty for right-wing prisoners and 'a recognition of the Christian faith' (Chandler 1997) indicates that religious intolerance is alive and well in South Africa.

${ }^{6}$ Lubbe (1995:32) says '... it can be asserted that while religious diversity has always been a reality of South African society, many Christians have been only vaguely aware of the presence of people of other faiths'. An important contributing factor in this regard was the apartheid policy which successfully isolated communities from each other.

${ }^{7} \mathrm{~J} J$ Kritzinger (1993:10) is of the opinion that the 1980 census was the last that gives a fairly accurate religious picture, as the 1985 census did not ask for religious information, and the 1991 census made religious information expressly optional.

${ }^{8}$ Cf J J Kritzinger (1993:1): '...we have to face the fact that South Africa is overwhelmingly "Christian" (in statistical terms)".

"See Van der Ven, Dreyer and Pieterse (1997) for a discussion of this finding.

${ }^{10}$ It is possible that this figure could be slightly higher because of the absence of a category for African Traditional Religions. See Van der Ven, Dreyer and Pieterse (1997). It is important to keep in mind that although such a vast majority of South Africans claim some connection with a church, it 'does not imply strong commitment to the Christian faith on the part of all' (De Gruchy 1995:220).

"Krüger (1994:5) refers to this as the internal aspect of pluralism.

19. :...we need to understand that there is no (one) monolithic Islam in South Africa. There are a number of diverse articulations or brands of Islam, if you will, frequently locked in fierce rivalry in their claims to be the privileged, orthodox and authentic voice of Islam in South Africa' (Omar 1991:49),

${ }^{13}$ Krüger (1994:3) calls this the external aspect of pluralism.

${ }^{14}$ From the 1980 and 1991 censuses J Kritzinger (1993:2) concludes that the adherents of the 'world religions' are relatively few and that Christians form an overwhelming majority. 
${ }^{15}$ Not everyone agrees that South Africa is a religiously pluralistic country. Stegen (1993:125) says: 'The idea that we are a pluralistic, multi-faith society is not justifiable when one considers that Muslims, Jews, Hindus, Bahai and Buddhists together comprise less that 5 per cent (sic) of the population.' There is consensus, however, among the scholars of religious studies in South Africa that South Africa is a religiously plural country (cf Chidester 1992; Krüger 1994; Krüger, Lubbe \& Steyn 1996; Lubbe 1995; Pobee 1993).

${ }^{16}$ Section 2 of the 1983 constitution stated: "The people of the Republic of South Africa acknowledge the sovereignty and guidance of Almighty God' (cf Du Plessis 1996:60).

${ }^{17}$ An interesting feature of the religious diversity in South Africa is that the adherents of religions other than Christianity, with the exception of a small number of Jews, white Buddhists and white Muslims, are all black (Lubbe 1995:32). Issues of ethnicity and faith thus came to be inextricably connected. It is impossible to deal constructively with religious diversity in South Africa without paying attention to the damage done by the policy of apartheid.

${ }^{18}$ Since the occupation of the Cape by the Dutch East India Company in 1652 Christianity was favoured by the political powers. According to Omar (1993:74) the Placaten in terms of which the Cape was administered were noted for their strong Calvinist tenor. The public practice of Islam at the Cape was prohibited, and Islam was only tolerated at the private level, until the Maetsuyker restrictions on religious freedom were scrapped in 1804 . Even then Muslims were constantly persecuted, harassed, arbitrarily arrested because of their Islamic faith, discriminated against, and the objects of efforts to convert them to Christianity (Omar 1993:75-76).

19. Van der Westhuizen and Heyns (1993:99) mentions section 2(1)(a) of the National Education Policy Act 39 of 1967 and section 3(a) of the Education and Training Act 90 of 1979.

"on In practice the censorship was dictated by so-called Christian morality and more specifically a specific type of Christianity, namely a Calvinist brand (cf Van der Westhuizen \& Heyns 1993:99-100).

21 Saayman (1993:42) also mentions that Hindu and Muslim marriages were not legally recognised, and Buddhists did not qualify for the right to conscientious objection until a Supreme Court case ruled otherwise in 1986.

․․ See note 17 .

2:3 Omar (1993:77) says: '... the apartheid regime saw itself as a Christian state ...'

${ }^{24}$ Of all the major political parties, only the Inkatha Freedom Party (IFP) withdrew from the constitution-making process.

${ }^{25}$ The following section on religious rights and the new Constitution is based on Du Plessis (1996).

"26 A secular state does not mean that the state is antireligious but that the state does not favour one religion.

${ }^{97}$ Section 9(1).

${ }^{28}$ Section $9(3)$.

29 Section $31(1)$. 
${ }^{30}$ 'The high political profile which the church once enjoyed in South Africa is a thing of the past' (Villa-Vicencio 1994:95).

"See Petersen (1996:80). According to Petersen the question of religious pluralism was seen as irrelevant by many stalwarts of the struggle against apartheid: 'For in many ways, the theological struggle against apartheid was an inner-Christian struggle - a struggle against heresy and for the soul of the church seen as a site of struggle. The question of religious pluralism, and a theology of the world religions was seen to be irrelevant. No longer. It is, particularly but not exclusively in the Western Cape, one of the challenges that has yet to be adequately grasped.'

${ }^{32}$ See Sections 9(3) and 9(4) of the new Constitution. Section 9(3): The state may not unfairly discriminate directly or indirectly against anyone on one or more grounds, including race, gender, sex, pregnancy, marital status, ethnic or social origin, colour, sexual orientation, age, disability, religion, conscience, belief, culture, language and birth. Section 9(4): No person may unfairly discriminate directly or indirectly against anyone on one or more grounds in terms of subsection (3). National legislation must be enacted to prevent or prohibit unfair discrimination.

"3s In a report on new publications on interreligious dialogue, Ziebertz (1992:85) remarks that the number of publications dealing with this issue has increased dramatically in the past few years. See also Bosch (1991:477).

${ }^{34}$ Bosch (1991:478-483) prefers to work with the three fundamental positions of exclusivism, fulfilment and relativism.

${ }^{35}$ See McGrath (1994:459-464) and Netland (1986). J N J Kritzinger (1997) refers to the well-known threefold distinction between exclusivism, inclusivism and pluralism which 'has become commonplace in the theology of religions due to the influence of the seminal work by Race (1983)...' Knitter (1995:25) says in his overview of current models that 'it seems better to sacrifice precision to clarity and to follow the neat classification, first provided I believe by Alan Race (1983), of exclusivism, inclusivism, and pluralism'. He refers to complaints against the rigidity and simplicity of these models, but concludes (1995:25-26) that if we recognize the limitations of all models, if we are always open to modifying and expanding our models, it seems to me that these three classifications represent in broad lines the differing presuppositions and approaches within recent Christian efforts to make sense of the many religions. Such models are limited, possibly dangerous, but also useful.'

${ }^{36}$ Race (1983:11) maintains that the inspiration for the exclusivistic position comes chiefly from the Protestant theologians Barth, Brunner and Kraemer, with Barth as the exponent of the most extreme form of the exclusivistic theory.

${ }^{37}$ See Race (1983:24-37) for a discussion of some of the theological, philosophical and historical problems of this approach. According to him (1983:36) exclusivism has no answer to the questions raised by current epistemological considerations or the new historical perspective.

${ }^{38}$ See Rahner's third thesis for a Christian theology of religions (quoted by Race 1983:47): '...Christianity does not simply confront the members of an extra-Christian religion as a mere non-Christian but as someone who can and 
must already be regarded in this or that respect as an anonymous Christian'. Bosch (1991:481) places Rahner under the model of fulfilment. According to him, Rahner represents the move from an ecclesiocentric to a christocentric approach to the theology of religions. Bosch (1991:481) says that Rahner 'never abandons the idea of Christianity as the absolute religion and of salvation having to come only through Christ'.

${ }^{99}$ Race (1983:71) says there is only one early instance of pluralism worthy of mention, namely the publication De Pace Fidei of Cardinal Nicholas of Cusa in the middle of the fifteenth century.

${ }^{40}$ For authors such as Hick (1985), Knitter $(1985 ; 1995 ; 1996)$ and Panikkar (1995) that opt for the model of pluralism this cultural relatedness means that the normativity of Christ has to be questioned, and that all religions are equally valid (cf Bosch 1991:482). This can be described as a move from christocentrism to theocentrism.

${ }^{41}$ See Knitter (1995:23-24; 43-44) for some of the problems of a pluralist model, especially the reduction of the pluralist model to relativism or a relativising perspective. Knitter(1995:31) refers to the abhorrence of relativism. He points to another understanding of the pluralist model, namely that of a correlational dialogue among religions, in which 'salvation' or the 'wellbeing' of humans and the Earth could be taken as the starting-point and common ground of the interreligious dialogue (Knitter 1995: 17).

42 Race's third model implies an objective and comparative approach to the multitude of religions. The aim is not to search for the truth or the way to salvation, but to consider religious matters from a more or less neutral 'it' or observer perspective. Race's model of pluralism thus seems to be more related to the relativistic variety of pluralisn as it emphasises that all religions have equally valid truth claims, that differences between the religions do not really matter and that all religions are essentially the same (cf Knitter 1995:2324; 31). Race (1983:90) is well aware of the problem of relativism. He writes: "The pertinent question mark which hovers over all theories of pluralism is how far they succeed in overcoming the sense of "debilitating relativism" which is their apparent danger.'

${ }^{13}$ Ziebertz (1993:90) says that religious-philosophical and religiouspsychological patterns of thought inevitably end in relativism regarding religious truth.

${ }^{44}$ Küng (Küng et al 1993:xix) for example writes: 'But at the same time neither will anyone expect me as a Christian theologian to maintain a superficial and irresponsible relativism (of Christian, Hindu, or Buddhist provenience) that relativizes all truth and nonchalantly equates all values and standards. I consider an arbitrary pluralism untenable, the view that approves and endorses without differentiation both one's own and the other religions ...'

${ }^{4.5}$ Heim (1995:1) writes that the familiar maxim of religious studies "Those who know only their own religion, know none' should be complemented by the maxim 'Those who are not decisively committed to one faith, know no others'. Interreligious dialogue requires commitment (Bosch 1991:484). Knitter (1985:207) shares the view that dialogue 'must be based on personal religious 
experience and firm tmuth claims'. From the perspective of Christian religious education Nipkow (1990:19-20) stresses the importance of the formation of confessional Christian and general Christian identities which could form the basis of interreligious understanding and dialogue: 'We assume that an understanding of ecumenical relations will not develop independently of an understanding of the nature and relative value of denomination, or confessional affiliation from within just as well as an understanding of inter-religious relations will not develop before, or independently of, an understanding coming from within the experience of a specific world religion' (Nipkow 1990:7).

${ }^{46}$ Available from the authors.

${ }^{17}$ This sample shows the following demographic characteristics: $49 \%$ are boys, $51 \%$ girls; $67 \%$ of them have English as their home language and $33 \%$ one of the ten other official languages; the highest education level of $26 \%$ of their fathers and $34 \%$ of their mothers is Standard 1 through 10 (Grades 3 to 12), that of $48 \%$ of their fathers and $54 \%$ of their mothers is some form of continuous education beyond Standard 10 (Grade 12), whereas $27 \%$ of their fathers and $12 \%$ of their mothers have a master's or doctoral degree; $34 \%$ support the ANC, 25\% the Democratic Party, 29\% the National Party, whereas $12 \%$ support other parties; $31 \%$ of them are Catholic, $26 \%$ Anglican, $8 \%$ Methodist, $23 \%$ belong to another Christian community, $8 \%$ to another religion, whereas $4 \%$ say they do not belong to any religion.

${ }^{18}$ For the statistical conventions we followed in the factor analyses we conducted for this article, see Van der Ven (1993). The factor analysis output used in this article is available from the authors.

19. The empirical domain is indicated by text boxes.

${ }^{50}$ In a pilot study (130 students from Standards 6 to 8 in a secondary school in the south of the Netherlands) on the interaction between world religions Van der Ven (1994:248-249) also found that the students did not distinguish between the exclusivistic (confessional) and inclusivistic models. In a survey among 900 Roman Catholic and Evangelical teachers of religion in the north of Germany exclusivism and inclusivism also form one factor (cf Ziebertz 1993; 1994). Ziebertz (1993:92) labelled this orientation 'exclusive inclusivism'.

${ }^{51}$ Sterkens, Hermans and Van der Ven (1997:1 1-29) differentiate between a monoreligious model (with exclusivistic and inclusivistic variants), a multireligious model and an interreligious model. They argue that the traditional, absolutistic truth claim of Christianity provides the normative basis for both the exclusivistic and inclusivistic variants of their monoreligious model (Sterkens, Hermans \& Van der Ven 1997:11).

52 See Van der Ven (1994:251) for a discussion of an equivalent case.

${ }^{53}$ The item reads: "The way to real salvation is only to be found in dialogue between the religions.'

is This item reads: 'Before finding authentic (real) redemption religions must enter into dialogue with each other.'

55 'Redemption in the Christian sense is seen as something 'objective'; ie as an event and its consequence (objective redemption) which in fact precede 
human justification and sanctification (subjective redemption)' (Rahner \& Vorgrimler 1983:432).

${ }^{56}$ The items are: 'God is only found in the meeting between religions' and 'The real truth can only be discovered in the communication between the religions'.

${ }^{57}$ See Van der Ven 1994:255-256. Although the factor structure in the pilot study referred to above was different, it was found that the confessionalmonoreligious model and the multireligious model were to some degree $(\mathrm{r}$ .18) each other's opposites.

${ }^{58}$ The scales run from 1 (very negative) through 5 (very positive). We interpret scores 1.00 through 1.79 as very negative, 1.80 through 2.59 as negative, 2.60 through 3.39 as half negative/half positive, 3.40 through 4.19 as positive, and 4.20 through 5.00 as very positive.

${ }^{59}$ The average score on this factor in the empirical pilot study referred to in note 50 was even lower (1.54), which means that the students even more strongly rejected this orientation (Van der Ven 1994:248-249).

${ }^{100}$ It is interesting to note that the position of relativism (multireligious orientation) also receives the highest score (3.84) in the research by Ziebertz (1993). The average score (3.43) on this factor in the empirical pilot study by Van der Ven (1994:251) was also the highest.

i) Research among students in western Europe indicated that students reject an absolutistic (or monoreligious) orientation and favour a relativistic (or multireligious) orientation (cf Nipkow 1994:224; Van der Ven 1994:250_ 251).

62 Although we have not studied the religious education policies of these schools, we suspect that they adopted a multireligious rather than a confessional approach to religious education.

is. See note 47 for the religious preferences of the students in our sample. Although $57 \%$ of the students in this sample regard themselves as belonging to the Anglican or Catholic church, 31\% belong to another Cliristian community and $12 \%$ to another religion or no religion at all.

is The different histories and the 'democratic ethos' of these Anglican and Catholic private schools clearly separate them from the public schools. This sample can therefore not be taken as representative of South African youth in general.

${ }^{65}$ We are aware that this interpretation of the research results, which is biased towards interreligious tolerance in the meeting between religions, will not go unchallenged in intercultural and interreligious relations.

${ }_{66}$ Cooling (1994:45) writes: Acceptance of relativism is supposed to generate a humility that is conducive to a ready acceptance of those with whom we disagree'. He argues, however, that relativism is not necessarily a basis for tolerance, and concludes that "it appears that relativism is somewhat of a lame duck when it comes to providing the basis for respect and tolerance between religions' (Cooling 1994:46).

${ }^{67}$ See J N J Kritzinger (1997) for some interesting ideas on the relations 
between theological models (exclusivism, inclusivism and pluralism) and patterns of interfaith encounter.

\section{BIBLIOGRAPHY}

Bosch, D J 1991. Transforming mission: paradigm shifts in theology of mission. Maryknoll, New York: Orbis.

Chandler, N 1997. Agencies 'knew of rightist terror plans'. The Pretoria Neus, 7 January.

Chinester, D 1992. Religions of South Africa. London: Routledge.

Chiofster, D, Mrtchell., G, OMar, A R \& Pinri, I A 1994. Religion in public education: options for a new South Africa.) Cape Town: UCT Press.

Ci.AAsEN, J W 1995. Independents made dependents. Journal of Theology for Southern Africa 91:15-34.

CoOIIN(, T 1994. A Christian vision for state education: reflections on the theology of education. London: SPCK.

De Gruchy, J W 1994. Midwives of democracy. The role of the churches in democratic transition in South Africa. Journal of Theology for Southern Africa 86 (March):4-25.

De Gruchy, J W 1995. Christianity and democracy. Cape Town: David Philip.

Du Ptessis, L 1996. A Christian assessment of aspects of the Bill of Rights in South Africa's Final Constitution. Journal of Theology for Southern Africa 96:59-74.

Gutman, A (ed) 1994. Multiculturalism: examining the politics of recognition. Princeton: Princeton University Press.

Heim, S M 1995. Salvations: Truth and difference in religion. Maryknoll: Orbis.

HıCK, J 1985. Problems of religious pluralism. Hampshire: Macmillan.

KNITTER, P F 1985. No other name? A critical survey of Christian attitudes toward the world religions. London: SCM.

KNITTKR, P F 1995. One earth, many religions: multifaith dialogue and global responsibility. Maryknoll: Orbis.

KNITIER, P F 1996. Jesus and the other names: Christian mission and glabal responsibility. Maryknoll: Orbis.

KRITZINGFR, J J 1993. The religious scene in present-day South Africa. In Kilian, $\mathrm{J}$ (ed) Religious freedom in South Africa. Pretoria: University of South Africa.

KrTTZincti, J N J 1997. Interreligious dialogue: problems and perspectives. A Christian theological approach. Scriptura 60(1):47-61.

KrÜCER, J S 1994. From one to many: The challenge of religious pluralism. Pretoria: C B Powell Bible Centre, Unisa.

Krüger, J S, Lubir:, G J A \& Steyn, H C 1996. The human search for meaning. Pretoria: Via Afrika.

Künci, H, VAn Ess, J, Von StItitencron, H \& Bechiert, H 1993. Christianity and uorld religions. Paths of dialogue with Islam, Hinduism, and Buddhism. Maryknoll, New York: Orbis.

Luise, G J A 1995. Declaration of religious rights and responsibilities: the 
South African context. Areopagus 8(1):31-35.

McGrath, A E 1994. Christian theology: an introduction. Oxford: Blackwell.

NetLAND, H 1986. The challenge of religious pluralism. TSF Bulletin 10(1):2025.

Nır'Kow, K E 1990. Ecumenical and inter-religious education. Journal of Empirical Theology 3(2):5-22.

NıpKow, K E 1994. Ziele Interreligiösen Lernens als mehrdimensionales Problem. In Van der Ven, J A \& Ziebertz, H-G (ed) Religiöser Pluralismus und Interreligiöses Lernen. Kampen/Weinheim: Kok/Deutscher Studien Verlag (Theologie en Empirie 20).

OMAR, A R 1991. The perils of the third option: a Muslim response to Albie Sachs. In Kritzinger, J N J (ed) Believers in the future: Proceedings of the $\mathrm{Na}$ tional Inter-faith Conference on Religion-State Relations, December 2-4, 1990, Johannesburg. Pretoria: WCRP - SA.

Omak, A R 1993. An Islamic experience of religious freedom in the South African context. In Kilian, J (ed.) Religious freedom in South Africa. Pretoria: University of South Africa.

PANIKKaR, R 1995. Invisible harmony: essays on contemplation and responsibility. Minneapolis: Fortress.

PEtersen, R 1996. Soweto to the millennium: changing paradigms of South African prophetic theology. Journal of Theology for Southern Africa 1996:7681 .

P(oвkE, J S 1993. Religion and politics in sub-Saharan Africa. Journal of Theology for Southern Africa 83:14-19.

Population Census 1991. Summarised results after adjustment for undercount. No. 03-01-01. Pretoria: Central Statistical Service.

Prozesky, M 1995. Introduction. In Prozesky, M \& De Gruchy, J (eds) Living faiths in South Africa. Cape Town: David Philip.

RACE, A 1983. Christians and religious pluralism: patterns in the Christian theology of religions. London: SCM.

Rahner, K \& VORcirimi.er, H 1983. Concise theological dictionary. London: Burns \& Oates.

Report on Christianity, the Secular State and Constitutionalism, Conference held in Somerset West 7 \& 8 November 1995. 1996. Journal of Theology for Southern Africa, 94:79-85.

SAAYMAN, W A 1993. Religious freedom in apartheid South Africa. In Kilian, J (ed) Religious freedom in South Africa:37-47. Pretoria: University of South Africa.

SANNFII, L 1993. Encountering the West. Christianity and the global cultural process: the African dimension. London: Marshall Pickering.

STEcien, E 1993. A Christian experience of religious freedom in the South African context. In Kilian, J (ed) Religious freedom in South Africa. Pretoria: University of South Africa.

Sterkens, C, Hermans, C A M \& VAN Der Vhin, J A 1997. Interreligieus leren op de basisschool. Nijmegen: Nijmeegs Instituut voor Studies in de Empirische Theologie. (Verslag SVO-project 92085) 
TRACY, D 1990. Dialogue with the other: the inter-religious dialogue. Louvain: Peeters. To, C-Y \& Tulasiewicz, W 1993. Conclusion. In Tulasiewicz, W \& To, C-Y (eds) World religions and educational practice. New York: Cassell.

VAN Der Ven, J A 1993. Practical theology: an empirical approach. Kampen: Kok Pharos.

VAN DER VEN, J A 1994. Religious values in the interreligious dialogue. Religion EF Theology 1(3): 244-260.

Van 1etr Ven, J A, Dreyer, J S \& Pietterse, H J C 1997. Belief in God among South African youth and its relation to their religious socialization and praxis. Hervormde Teologiese Studies, 53(3):864-880.

VAN DER Westi IUIZEN, J V \& HeYNS, C H 1993. A legal perspective on religious freedom. In Kilian, J (ed) Religious freedom in South Africa. Pretoria: University of South Africa.

VILLA-VICENCIO, C 1992. A theology of reconstruction: nation-building and human rights. Cape Town: David Philip.

Vil.LA-Vicencio, C 1994. Are we still of any use? A question of social significance. In Du Toit, C W (ed) Sociopolitical changes and the challenge to Christianity in South Africa. Pretoria: University of South Africa.

Wat.nfNFrls, H 1990. Begegnung der Religionen. Bonn: Borengässer.

ZiEBERTZ, H-G 1992. Religions in dialogue: a report on new publications. Journal of Empirical Theology 5(1):85-95.

ZieвекI\%, H-G 1993. Religious pluralism and religious education. Journal of Empirical Theology 6(2):82-99.

ZifberTT, H-G 1994. Religionspädagogik als empirische Wissenschaft: Beiträge zu Theorie und Forschungspraxis. Weinheim: Deutscher Studien Verlag. 